in $70 \%$ of trials, in preference to BALB

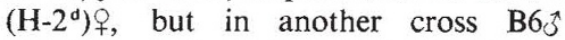
$\left(\mathrm{H}-2^{\mathrm{b}}\right)$ showed a preference for $\mathrm{B} 6-\mathrm{H}-2^{\mathrm{k}}{ }^{\mathrm{q}}$, and $\mathrm{B} 6-\mathrm{H}-2^{\mathrm{k}} \mathrm{o}$ for $\mathrm{B} 6$ \% , rather than for the partner of their own $\mathrm{H}-2$ type. The experimenters used $\mathrm{H}-2$ congenic mice to avoid confusing influences from the genetic background.

This very strange and remarkable phenomenon was appropriately discovered at the Sloan-Kettering Memorial Cancer Center since it was the SloanKettering's President, Lewis Thomas, who first suggested at the second International Congress of Immunology in Brighton in 1974, that the diversity of histocompatibility antigens might be used by animals to identify each other, presumably by smell, thus drawing together two of his persistent interests, immunology and pheromones.

There are many aspects of these findings that need further clarification: do the females do any choosing, or do they merely wait to be chosen? Is the stimulus indeed a smell, and if so from where (the urine?), and precisely what is smelly? Histocompatibility antigens are not obvious candidates for airborne pheromones: perhaps the association with $\mathrm{H}-2$ is indirect, through metabolites from characteristic bacterial flora infesting the skin, or intestinal and genitourinary tracts, the presence of particular organisms being under the control of H-2 linked Ir genes. In this context it was reported a few years ago that the bacterial flora of the human skin was indeed individual, as assessed by characteristic patterns of phage sensitivity, and of course the individuality of human odour has long been known, at least to dogs.

The biological significance of these complex phenomena is not clear. As Thomas and others have pointed out, the recognition of individuals is important for animals with a developed social structure. The $\mathrm{H}-2$ associated mating preferences demonstrated by Lewis Thomas and his colleagues have two additional interesting consequences. In so far as the mating preferences are disassortative they will encourage the persistence of $\mathrm{H}-2$ polymorphism. For a long time, evolutionarily inclined imunologists (and indeed immunologically inclined evolutionists such as J. B. S. Haldane) have been looking for possible 'external' reasons why $\mathrm{H}-2$ polymorphism should be so extensive and so persistent. Until very recently there were no good clues. For a time the effect of H-2 incompatibility on placental weight in mice was offered as a mechanism for the maintenance of the polymorphism: foetuses $\mathrm{H}-2$ incompatible with their mothers had larger placentas and a heavier birth weight than $\mathrm{H}-2$ compatible foetuses in the same pregnancy. There were difficulties in repeating the work, and it has now dropped out of fashion.

\section{Palmdale bulge changes shape}

\section{from Peter J. Smith}

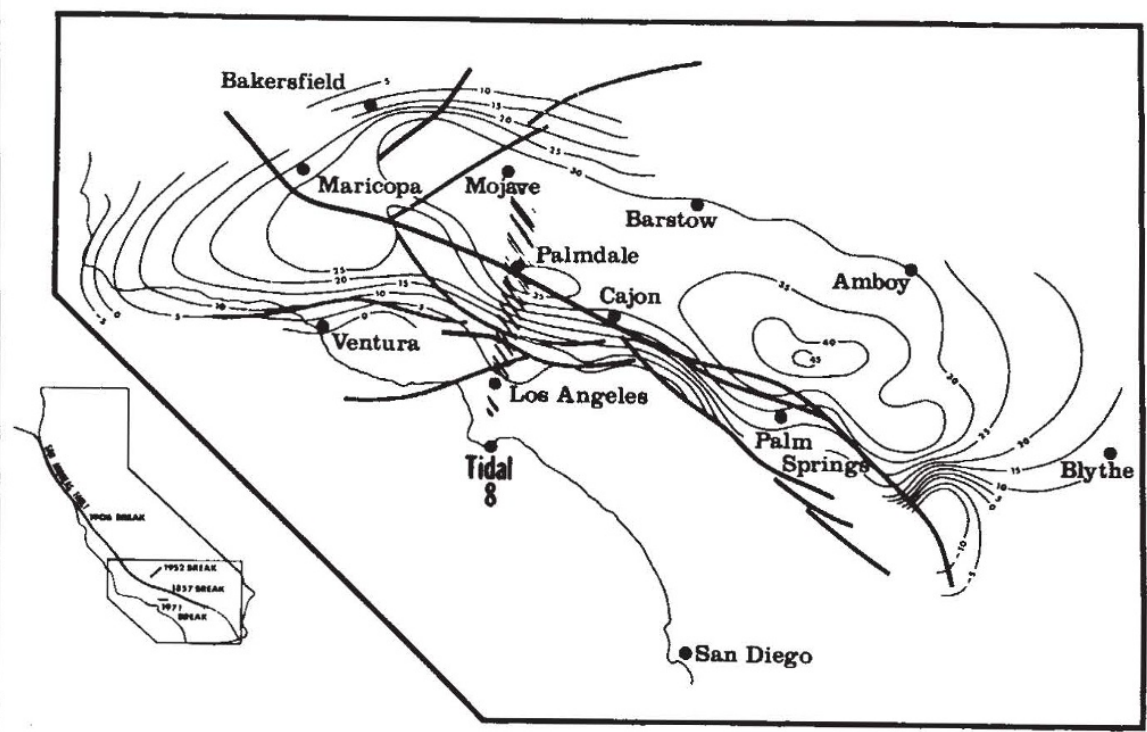

Ir is just about a year since Castle et al. (Science 192, 251; 1976) reported their discovery of the crustal bulge centred near the town of Palmdale about $65 \mathrm{~km}$ north of Los Angeles. This uplift, which apparently began about 1960, had by 1974 reached more than $0.35 \mathrm{~m}$ at its highest point and was observable over an area of at least $12,000 \mathrm{~km}^{2}$ of southern California. Interest in the bulge was enhanced by the fact that Palmdale lies almost on the San Andreas fault and by the discovery that the uplift contours were elongated along the fault over a distance of more than $150 \mathrm{~km}$. Moreover, most of the area with an uplift greater than $0.15 \mathrm{~m}$ had remained virtually aseismic since at least 1932 . The possibility that the bulge might herald a major earthquake therefore had to be taken seriously.

No such earthquake has yet occurred, but a new analysis of historical and recently acquired geodetic data, announced this month by the US Geological Survey, reveals that the uplift covers a much wider area than previously supposed and that part of it has collapsed since 1974. The zone originally studied by Castle and his colleagues lies between Maricopa and Cajon (see map); but it is now evident that uplift extends at least as far as Blythe in the southeast. The bulge thus stretches for at

Furthermore its universal significance as a mechanism for maintaining polymorphism seemed doubtful when it was realised that it was hardly applicable to the birds!

More recently Doherty and Zinkernagel provided a simple mechanism for least $600 \mathrm{~km}$ along the San Andreas fault and covers an area of more than $90,000 \mathrm{~km}^{2}$. Moreover, there is a second peak of uplift (between Palm Springs and Amboy) which is actually greater than the Palmdale peak in 1974.

Since 1974, however, the uplift in the vicinity of Palmdale itself has been reduced by about $0.18 \mathrm{~m}$. The significance of this depression is unclear, although the area has seen similar behaviour before. A less well documented uplift of possibly as much as $0.30 \mathrm{~m}$ took place sometime between 1897 and 1914 but had almost disappeared by 1926 , which has led Castle to speculate that "the recent deformation may be but a part of a generally cyclic process".

It may be significant that no major earthquake can be associated with the earlier episode of uplift and collapse, which would seem to imply that the present deformation does not necessarily indicate an imminent earthquake. On the other hand, uplift definitely preceded the 1961 Niigata (Japan), the 1971 San Fernando (California) and the 1975 Haicheng (China) earthquakes, among others. The 'Palmdale bulge' may or may not pose a problem to the residents of southern California, therefore. The only thing to do for the time being is to continue to observe it as closely as possible. heterozygous advantage in $\mathrm{H}-2$ when they showed that viral antigens on cell surfaces were recognised in association with $\mathrm{H}-2$ specificities. The virus-infected $\mathrm{H}-2$ heterozygote is thus able to display a more varied antigenic stimulus to itself than the homozygote, with a 